\title{
Salário e Produtividade
}

Célio Fonseca

É

inegável o esfôrço que vem desenvolvendo o Govêrno em busca da reformulação da máquina administrativa do serviço público, dando-lhe maior produtividade e eficiência.

A reforma administrativa de que está cuidando o Ministério do Planejamento, sob o comando experiente e lúcido do Ministro Hélio Beltrão, já tem produzido efeitos palpáveis, notadamente no que diz respeito à simplificação burocrática que se vem ubtendo pela delegação de autoridade, aliviando paulatinamente os escalões mais elevados em benefício das tarefas de orientação, supervisão e decisões de mais alto nivel.

A maneira objetiva e prática com que o eminente técnico conduz o problema constitui, sem dúvida, uma esperança de sucesso já tantas vêzes tentado por procedimentos até então marcados por excessivo tecnicismo, justificado por extensas explanações teóricas inteiramente distanciadas da realidade do serviço páblico brasileiro.

Em verdade, não se pode apontar uma ou apenas algumas causas do emperramento da máquina administrativa. Os motivos são vários e complexos e decorrem da conjuntura brasileira, com seus problemas sociais, econômicos, políticos etc. É evidente que a eficiência administrativa não pode ser obtida sem adequados estudos de racionalização das rotinas administrativas, estruturação conveniente dos órgãos, seleção e aperfeiçoamento do pessoal e tantos outros problemas que concorrem no complexo administrativo.

Todavia, notamos uma lacuna em todos os estudos e esforços feitos nesse campo, em que se tem sempre neglicenciado aspecto que nos parece fundamental e capaz de frustrar completamente os objetivos procurados. Referimo-nos ao contrôle da produtividade do servidor com reflexos no seu salário ou remuneração. Isto se pratica freqüientemente nas emprêsas privadas, atribuindo-se ao empregado, além da remuneração-base, o adicional salário-produção, que atua como poderoso fator de estímulo, fazendo-se justiça àqueles que são mais capazes e que mais produzem. 
Tal problema tem sido focalizado às vêzes, porém tìnidamente, e apenas como elemento concorrente, sem qualquer predominância no conjunto, quando, a nosso ver, não obstante as previsíveis dificuldades de execução, deveria constituir ponto fundamental e objetivo básico a alcançar, mesmo que o fôsse a longo prazo e progressivamente.

Não desconhecemos as dificuldades de implantação de tal regime na problemática do serviço público, o que, entretanto, não deve representar óbice intransponivel. Estudos objetivos, com critérios menos rígidos e específicos para cada pequena unidade de execução, cremos que podem conduzir à solução adequada. $\mathrm{Na}$ impossibilidade de mensuração física das tarefas, pode-se, em muitos casos, recorrer a métodos estatísticos e a outros processos de avaliação indireta compativeis com os vários tipos de trabalho.

Não se pode negar que o sistema atual de nivelameno salarial segundo os cargos e niveis é profundamente injusto e altamente desestimulante por não levar em conta a capacidade e produtividade do servidor.

Não se diga que tal processo seria oneroso, pois talvez possibilitasse até, não só progressiva diminuição de custos dos serviços pelo aumento da produção do funcionário, como também paulatina redução do pessoal.

Ao contrário, oneroso se nos afigura o atual sistema, onde observamos que, embora inegàvelmente baixos os niveis salariais do funcionalismo, considerável número existe que nem a êsse minimo faz jus, dada a pequena produção apresentada.

Ao invés, se o salário do servidor fôsse estabelecido $\mathrm{em}$ duas parcelas, uma básica, mínima, que não constituísse por si só atrativo, e outra variável de acôrdo com a produtividade, obter-se-ia, com o tempo, a diminuição dos incapazes e ociosos no serviço público, com a conseqüente redução de custos.

Com êsse objetivo de vincular a remuneração à produtividade, pode-se ainda, sempre que exeqüivel, buscar a contratação de serviços com emprêsas privadas, quando se dispuser, é claro, de firmas habilitadas a executá-los e se trate de tipos de tarefas de difícil contrôle de produção. É o caso, por exemplo, de serviços de conservação, limpeza, guarda e vigilância de edificios e locais de trabalho.

Como êsses trabalhos, muitos outros oferecem a possibilidade de se adjudicarem a entidades privadas, o que dá à administração pública segurança de execução a custo certo, prèviamente, examinado, e julgado conveniente.

Tais procedimentos nos parecem perfeitamente possiveis, desde que examinados e julgados convenientes.

Tais procedimentos nos parecem perfeitamente possiveis, desde que tentados paulatinamente e com, as necessárias cautelas, bastan- 
do que a administração se liberte dos velhos e superados conceitos de padronização e uniformização exagerados, de normas que forçam a aplicação indiscriminada em todos os órgãos públicos centralizados, ou não, de padrões, critérios e gabaritos nada adequados às características e natureza de cada um e muito menos às yeculiaridades locais de suas unidades.

Mais correto seria que se desse a cada órgão ou mesmo a cada pequena unidade dêstes a necessária maleabilidade para ajustá-los às condições reais e locais, solucionando-se-lhes os problemas de maneira a mais conveniente, independentemente de padrões rígidos.

Essas duas alternativas, o salário-produção e a contratação de serviços, aliviariam o Govêrno do pesado ônus de pagar por um serviço que não recebe.

São essas as idéias básicas que sôbre o tema nos xcorrem, as quais deixamos ao exame e estudo dos especialistas, que, caso as achem de alguma forma aproveitáveis, poderão reestruturá-las e consubstanciá-las em normas objetivas de execução. 